\title{
A cytological analysis of the oral mucosa adjacent to orthodontic devices
}

\author{
Raul Magnoler Sampaio Mei, Antônio Adilson Soares de Lima ${ }^{1}$, Jorge César Borges Leão Filho ${ }^{2}$, \\ Orlando Motohiro Tanaka², Odilon Guariza Filho², Elisa Souza Camargo² \\ Graduate Dentistry Program, Orthodontics, Centro Universitário da Grande Dourados, \\ Dourados, ${ }^{1}$ Depatment for Stomatology, Universidade Federal do Paraná, Curitiba, ${ }^{2}$ Pontifícia \\ Universidade Católica do Paraná, Curitiba, School of Health and Biosciences, Dentistry Graduate \\ Program - Orthodontics, Brazil
}

\author{
Address for correspondence: \\ Prof. Dra. Elisa Souza Camargo, \\ Graduate Dentistry Program, \\ Orthodontics, Pontifícia Universidade \\ Católica do Paraná, Curitiba, \\ Rua Imaculada Conceição, 1155, Brazil. \\ E-mail:escamargo@uol.com.br
}

\begin{abstract}
Objectives: The objective of this study, was to evaluate the cytometry and cytomorphology of oral mucosa epithelial cells adjacent to orthodontic accessories using liquid-based exfoliative cytology. Materials and Methods: We placed metallic brackets on the upper pre-molars with stainless steel wires and metal or elastic ties on 20 people of both sexes, with an average age of 22.7 years. We evaluated nucleus area (NA), cytoplasm area (CA), and NA/CA ratio before installation (T0, baseline), 30 days after installation (T1), and 30 days after the accessories were removed (T2). Results: We verified a reduction in NA and an increase in

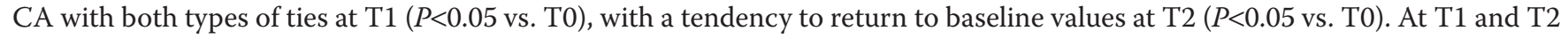
we observed a predominance of surface cells over subsurface cells. Conclusions: The orthodontic appliance causes adaptive cell changes characterized by an increased level of keratinization of the oral mucosa, with a tendency to return to the normal state after removal of the mechanical stimulus of the orthodontic devices.
\end{abstract}

Key words

Bracket, exfoliative cytology, mucosa

\section{INTRODUCTION}

During orthodontic treatment, it is necessary to install accessories such as brackets, arches and ties. These accessories, which come in contact with the oral mucosa, can lead to irritation, hematomas, erosions, and even ulceration of the oral mucosa, which can cause patients to have discomfort and pain. ${ }^{[1-3]}$ Pain arising from friction between the mucosa and these accessories is the reason why some patients abandon orthodontic treatment, ${ }^{[2]}$ although this discomfort tends to disappear after the first four weeks of treatment as the tissues adapt. ${ }^{[4]}$

Exfoliative cytology is a non-invasive alternative for examining oral lesions with a simple protocol based on the Papinicolau staining technique that is accepted as a reliable method. ${ }^{[5]}$ Relative to exfoliative

\begin{tabular}{|l|l|}
\hline \multicolumn{2}{|c|}{ Access this article online } \\
\hline Quick Response Code: & Website: \\
\cline { 1 - 2 } & www.ejgd.org \\
\cline { 2 - 2 } & \\
\hline
\end{tabular}

cytology traditional method, Liquid-based Exfoliative Cytology (LEC) has the advantage of reducing blood contamination, inflammatory cells and mucus, thus allowing a clear base and greater sensitivity, and thereby improving smear quality. ${ }^{[6,7]}$

Orthodontic treatments should produce as little tissue damage as possible; however, only a small number of studies have examined changes to the oral mucosa caused by friction with orthodontic appliances. Therefore, this study's objectives were to perform cytomorphometric and cytological analyses of the oral mucosa epithelium adjacent to metal brackets, stainless steel wires, and elastic or metal ties.

\section{MATERIALS AND METHODS}

The study's experimental protocol was approved by the Research Ethics Committee of (the name was omitted), case no $1389 / 08$.

\section{Sample}

We selected 20 participants with a mean age of 22.7 years old (range, 14-36), including 10 women and 10 men. The following exclusion criteria were applied: A history of smoking and alcoholism, debilitating diseases, use of 
mouthwash, treatment with antibiotics or steroids, use of a total or partial removable prosthesis and the presence of any type of lesion in the oral mucosa. Everyone who participated in the research signed an informed consent form.

\section{Installation of the accessories}

We placed metal brackets (Generus ${ }^{\circledR}$ Straight Wire "Roth" - GAC Orthomax, Bohemia, NY, USA) on each person's first and second upper right and left pre-molars. To position the brackets on the same horizontal axis, we used a 0.020-inch-thick stainless steel round guide wire (Shiny Bright ${ }^{\circledR}$, TP Orthodontics, La Porte, IN, USA), which was inserted into the brackets' slots before polymerization of the adhesive (Transbond $\mathrm{XT}^{\circledR}, 3 \mathrm{M}$ Unitek Orthodontic Product, Monrovia, CA, USA). After polymerization, we inserted another segment of the same stainless steel wire into the brackets' slots, folding them on their mesial and distal ends to prevent them from coming unwound. We fixed these wires with 0.012-inch-thick metal ties (Dentalloy ${ }^{\mathbb{R}}$, TP Orthodontics, La Porte, IN, USA) on the left side and elastic ties (Mini Stix Non-Coated ${ }^{\circledR}$, TP Orthodontics, La Porte, IN, USA) on the right side [Figure 1].

\section{Liquid-based exfoliative cytology}

We collected samples at three time points: Before installing the accessories (T0); 30 days after installing the accessories (T1); and 30 days after their removal (T2). Before starting each collection, we asked patients to rinse their mouth with water for 20 seconds. Next, we used a Universal Collection Medium (UCM) kit from the DNA-CITOLIQ system (Digene Brasil LTDA., São Paulo, Brazil) to collect mucosal cells by means of friction with a brush on the mucosa in the region adjacent to the brackets, moving the brush softly in five circular movements, clockwise. After applying this friction, we placed the brushes in the UCM solution, in accordance with the manufacturer's instructions.

Next, we transferred $200 \mu$ l of the loaded UCM solution to a polycarbonate membrane (Filtrogene, Digene Brasil LTDA., São Paulo, Brazil) using a pipette and a metal press (Prepgene, Digene Brasil LTDA., São Paulo, Brazil). We maintained the press closed for 10 seconds to generate an imprint of the material on the histology

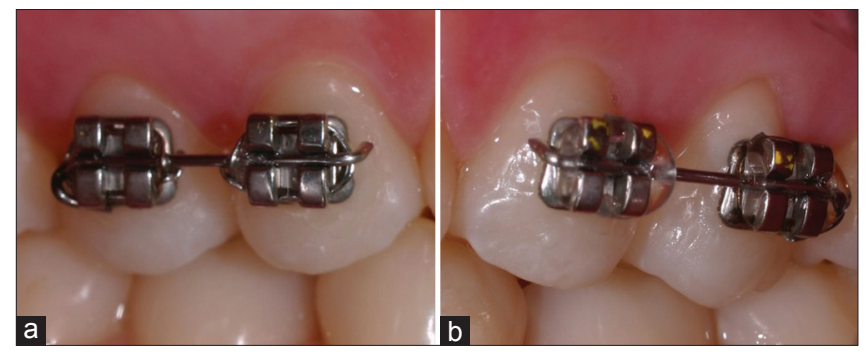

Figure 1: Photographs of brackets and write fixed with (a) metal and (b) elastic ties slide (Lamigene, Digene Brasil LTDA., São Paulo, Brazil). We immersed the slides in an absolute ethyl alcohol solution for 20 minutes to fix them and then stained them using the Papanicolau technique. ${ }^{[8]}$

\section{Cytomorphometry}

We analyzed the smears using a binocular optical microscope (Olympus BX50, Center Valley, PA, USA) with a WH 10×-H/22 lens and PLAN 40×/0.65 objectives. A calibrated examiner examined 50 cells on each slide. ${ }^{[9]}$ Areas in which the cells appeared doubled, agglomerated, or superimposed were avoided. Image capture of the cytological fields was performed with 400 times amplification using a CCD camera (model DXC-107A, Sony, New York, NY, USA). We evaluated the images using the Image Pro Plus program (version 4.5.029, Media Cybernetics, MD, Silver Spring, USA), in which, we defined the nucleus and cytoplasm of each cell. We then measured nucleus area (NA) and the cytoplasm area $(\mathrm{CA})$ in $\mu \mathrm{m}^{2}$. Finally, we calculated the ratio between the nucleus area/cytoplasm area (NA/CA) for each cell. ${ }^{[10]}$

\section{Cytomorphology}

For this analysis, we used the same binocular microscope used for cytomorphometry with a WH 10×-H/22 lens and PLAN $10 \times / 0.25,20 \times / 0.40$ and $40 \times / 0.65$ objectives. The slide was scanned completely and the smears were classified on the basis of the predominance of cells present, according to Sugerman and Savage. ${ }^{[1]}$

We performed a qualitative analysis of the smears to identify Papanicolaou's cytological criteria of malignancy. ${ }^{[8]}$ Briefly, class 0 indicates insufficient or inadequate material for analysis, class I indicates a normal smear, class II indicates a normal smear with inflammatory changes, class III indicates dysplastic changes (suspicious smear), class IV indicates that the smear is strongly indicative of malignancy but not conclusive and class $\mathrm{V}$ indicates that the smear is malignant.

\section{Statistical analysis}

We tabulated all the data and performed statistical tests using the Statistical Package for the Social Science 13.0 for Windows program. First, we performed the Kolmogorov-Smirnov test to verify whether the samples for the different groups (metal and elastic ties) and time points (T0, T1 and T2) were normal and Levene's homogeneity test to evaluate whether the data had variance homogeneity. Next, we applied the two-way analysis of variance (ANOVA) to compare the NA, CA and NA/CA variables according to type of tie (metal and elastic) and time point (TO, T1 and T2). When the ANOVA indicated that there was significant variance between the groups, we used Tukey's HSD multiple comparisons test to detect which of the groups differed from each other. To analyze the predominance of cells present, we determined the difference of two proportions test. 


\section{RESULTS}

The NA, CA, NA/CA means and standard deviations for the two types of ties at each of three experimental time points are reported in Table 1. Tukey's HSD multiple comparisons test results for NA, CA, NA/CA are reported in Table 2.

We observed a reduction in NA values $(P<0.05)$ and an increase in $\mathrm{CA}$ values $(P<0.05)$ between TO and T1 for both metal and elastic ties [Table 2]. These data verify that after 30 days of contact and friction with orthodontic devices, oral mucosa cells examined by exfoliative cytology responded to this irritation by increasing cytoplasmic volume and reducing nuclear volume. In addition, there was an increase in NA values $(P<0.05)$ and a reduction in $\mathrm{CA}$ values $(P<0.05)$ between $\mathrm{T} 1$ and $\mathrm{T} 2$, 30 days after removing the orthodontic devices [Table 2]. These observations demonstrate that mucosa cells tend to return to their normal morphology after the mechanical irritant has been removed. For the group with elastic ties, NA and CA values did not change significantly ( $P>0.05)$ between TO and T2, which indicates that oral mucosa cells can recover completely to their normal morphology within 30 days after the removal of orthodontic devices combined with elastic ties [Table 2].

None of the variables (NA, CA, and NA/CA) differed significantly between men and women at any of the time points. Moreover, the NA/CA ratio did not show any statistically significant group differences $(P>0.05)$ at any of the experimental periods.

With respect to the predominance of cells present in

\begin{tabular}{|c|c|c|c|c|c|}
\hline \multicolumn{6}{|c|}{$\begin{array}{l}\text { Table 1: Descriptive statistics for NA, CA, and NA/CA } \\
\text { at each time point }\end{array}$} \\
\hline \multirow[t]{2}{*}{ Variables } & \multirow[t]{2}{*}{ Time } & \multicolumn{2}{|c|}{ Metallic $(n=20)$} & \multicolumn{2}{|c|}{ Elastic $(n=20)$} \\
\hline & & Mean & S.D. & Mean & S.D. \\
\hline \multirow[t]{3}{*}{ NA } & To & 66,853 & 7,697 & 64,073 & 5,805 \\
\hline & $\mathrm{T}_{1}$ & 52,208 & 7,333 & 53,321 & 4,544 \\
\hline & $\mathrm{T}_{2}$ & 61,594 & 6,765 & 59,637 & 4,173 \\
\hline \multirow[t]{3}{*}{ CA } & To & $2,286,349$ & 227,107 & $2,338,914$ & 188,439 \\
\hline & $\mathrm{T}_{1}$ & $2,654,724$ & 205,881 & $2,608,837$ & 193,384 \\
\hline & $\mathrm{T}_{2}$ & $2,410,223$ & 196,529 & $2,439,367$ & 181,960 \\
\hline \multirow[t]{3}{*}{$\mathrm{NA} / \mathrm{CA}$} & To & 0,030 & 0,003 & 0,054 & 0,081 \\
\hline & $\mathrm{T}_{1}$ & 0,028 & 0,036 & 0,021 & 0,002 \\
\hline & $\mathrm{T}_{2}$ & 0,026 & 0,002 & 0,026 & 0,003 \\
\hline
\end{tabular}

NA - Nucleus area; CA - Cytoplasm area; T-Time; S.D. - Standard deviation the smears, no slide was found with a predominance of cells of the spinosum and basale stratum. In TO, the number of slides with a predominance of surface and subsurface cells was similar (P>0.05) in both metal and elastic ties groups. Between T1 and T2, a significantly higher number $(P>0.05)$ of slides showed a predominance of surface cells only in the group with metal ties. Between $\mathrm{T} 1$ and T2, was not observed a statistically significant change in the predominance of cells present in the smears for both groups [Table 3].

Smears that were examined exhibited no instances of Papanicolaou Classes 0, III, IV, and V when the cytologic criteria for malignancy were determined. Classes I (90.83\%) and II (9.16\%) were observed at all time points, and no significant difference was noted among the groups $(P>0.05)$.

\section{DISCUSSION}

The present study, demonstrated that orthodontic brackets and the wires associated with metal and elastic ties have the potential to induce an adaptive response in the oral mucosa. We observed the development of hyperplasia and light epithelial hyperkeratosis in response to the mechanical stimulus of orthodontic accessories.

We chose to expose the participants' oral mucosa to orthodontic devices for a period of 30 days because the period needed for total renewal of the epithelium of the cheek mucosa is 25 days. This epithelial renewal occurs under physiological conditions or when influenced by external stimuli. This period is the one needed for young basal epithelial cells to differentiate, reach the surface-most beds, and exfoliate. ${ }^{[12]}$

In analyzing the effects of the mechanical irritation promoted by orthodontic accessories on the NA and CA of mucosal epithelial cells, we found that NA decreased and CA increased significantly over a 30-day period after installation of brackets. These results are in line with those of a study in which Pereira et al. ${ }^{[13]}$ observed similar cellular changes caused by friction between the oral mucosa and metal and ceramic brackets. These changes to epithelial cells are part of an adaptive process that occurs together with an increase in the number of surface and subsurface cells ${ }^{[14]}$ of the

\begin{tabular}{|c|c|c|c|c|c|c|}
\hline \multirow[t]{2}{*}{ Variables } & \multicolumn{3}{|c|}{ Metallic } & \multicolumn{3}{|c|}{ Elastic } \\
\hline & ToxT1 & ToxT2 & $T_{1} \times T_{2}$ & ToxT1 & ToxT2 & $T_{1} \times T_{2}$ \\
\hline NA & $0.000122 *$ & $0.000441 *$ & $0.000122 *$ & $0.000122 *$ & $0.004011 *$ & $0.000129 *$ \\
\hline $\mathrm{CA}$ & $0.000122 *$ & $0.034358 *$ & $0.000122 *$ & $0.000122 *$ & 0.142981 & $0.001028 *$ \\
\hline $\mathrm{NA} / \mathrm{CA}$ & 0.999991 & 0.999498 & 0.999971 & 0.050000 & 0.128840 & 0.998774 \\
\hline
\end{tabular}

NA - Nucleus area; CA - Cytoplasm area; T-Time; * Statistically significant $(P<0.050)$ 


\begin{tabular}{|c|c|c|c|c|}
\hline \multicolumn{5}{|c|}{$\begin{array}{l}\text { Table 3: Quantity of smears according to cellular } \\
\text { predominance for each tie-type group and each } \\
\text { time point }\end{array}$} \\
\hline TimelTie & Superficial & Sub-superficial & Spinosum & Basale \\
\hline To metallic & 11 & 9 & 0 & 0 \\
\hline To elastic & 12 & 8 & o & o \\
\hline T1 metallic & 17 & 3 & 0 & 0 \\
\hline T1 elastic & 16 & 4 & 0 & o \\
\hline T2 metallic & 14 & 6 & o & o \\
\hline T2 elastic & 14 & 6 & o & o \\
\hline Total & 84 & 36 & o & o \\
\hline
\end{tabular}

oral mucosal epithelium (hyperplasia together with reactive hyperparakeratosis), following interaction with an irritant.

The CA of epithelial cells increases to allow an augmentation in metabolism and the synthesis of proteins important to tissue adaptation. ${ }^{[12]}$ Shabana et al. $^{\left[{ }^{[5]}\right.}$ also observed this process, verifying an increase in the size of cells subjected to traumatic lesions in comparison to normal cells.

After removing the mechanical stimulus, the epithelial tissue should return to its normal structure. ${ }^{[12]}$ Our study, revealed a tendency to return to conditions of morphological cell normality by 30 days after removal of orthodontic devices, as demonstrated by significantly increased NA and significantly reduced CA at T2 relative to T1 [Table 2]. Pereira et al. ${ }^{[13]}$ also observed this tendency of epithelial cells to return to normal conditions after withdrawal of orthodontic accessories. The lack of a gender effect in our study agrees with the findings of Cowpe et al. ${ }^{[9]}$

According to Berstein and Miller, ${ }^{[16]}$ normal cell morphology is characterized by abundant cytoplasm and a small, centralized singular nucleus. On the other hand, in oral mucosa cells that have some degree of dysplasia, there are morphological changes. Using cytomorphometric analysis, Ramaesh et al. ${ }^{[14]}$ demonstrated that dysplastic lesions and spinocellular carcinomas are associated with a gradual reduction in the diameter of the cytoplasm, relative to normal cells, in conjunction with a gradual shrinkage of nuclei. In our study, we did not observe changes in the morphological characteristics of smear cells obtained from mucosa that was in contact with orthodontic accessories. In fact, $90.83 \%$ of the smears were classified as Papanicolaou class I (normal) and $9.16 \%$ as class II (inflammatory). These findings are in line with those of Pereira et al., ${ }^{[13]}$ who verified that cellular changes in the oral mucosa arising from friction with orthodontic accessories are not suggestive of malignant transformation.

It is also important to consider other factors beyond mechanical stimulation that might contribute to the cellular changes observed in this study. One of these factors is cytotoxicity due to ion liberation from metallic orthodontic accessories. Prior studies ${ }^{[17-20]}$ have demonstrated that ions liberated by stainless steel orthodontic accessories (18\% chromium and $8 \%$ nickel) ${ }^{[21]}$ have a genotoxic effect on oral mucosa cells. However, this effect is reversible owing to cellular DNA repair mechanisms. ${ }^{[17,18]}$

\section{CONCLUSIONS}

Metal brackets, stainless steel wires and metal and elastic ties can induce cytomorphometric and cytomorphological changes to adjacent oral mucosa cells. This fact suggests an adaptive response to the physical stimulus, which is characterized by reactive hyperparakeratosis of the epithelium but which regresses when the irritant stimulus is withdrawn. Considering all the esthetic, functional and oral health benefits that orthodontic treatment brings and the fact that the mucosa's adaptive response to the injury caused by these accessories is reversible, we believe that the benefits of this treatment outweigh the disadvantages of discomfort and possible lesion of the oral mucosa.

\section{REFERENCES}

1. Arruda EP, Trevilatto PC, Camargo ES, Woyceichoski IE, Machado MA, Vieira I, et al. Preclinical alterations of oral epithelial cells in contact with orthodontic appliances. Biomed Pap Med Fac Univ Palacky Olomouc Czech Repub 2011;155:299-303.

2. Kluemper GT, Hiser DG, Rayens MK, Jay MJ. Efficacy of a wax containing benzocaine in the relief of oral mucosal pain caused by orthodontic appliances. Am J Orthod Dentofacial Orthop 2002;122:359-65.

3. Kvam E, Bondevik O, Gjerdet NR. Traumatic ulcers and pain in adults during orthodontic treatment. Community Dent Oral Epidemiol 1989;17:154-7.

4. Caniklioglu C, Ozturk Y. Patient discomfort: A comparison between lingual and labial fixed appliances. Angle Orthod 2005;75:86-91.

5. Maraki D, Becker J, Boecking A. Cytologic and DNA-cytometric very early diagnosis of oral cancer. J Oral Pathol Med 2004;33:398-404.

6. Hayama FH, Motta AC, Silva Ade P, Migliari DA. Liquid-based preparations versus conventional cytology: Specimen adequacy and diagnostic agreement in oral lesions. Med Oral Patol Oral Cir Bucal 2005;10:115-22.

7. Mehrotra R, Gupta A, Singh M, Ibrahim R. Application of cytology and molecular biology in diagnosing premalignant or malignant oral lesions. Mol Cancer 2006;5:11.

8. Lange DE, Meyer M, Hahn W. Oral exfoliative cytology in the diagnosis of viral and bullous lesions. J Periodontol 1972;43:433-7.

9. Cowpe JG, Longmore RB, Green MW. Quantitative exfoliative cytology of normal oral squames: An age, site and sex-related survey. J R Soc Med 1985;78:995-1004.

10. Ogden GR, Cowpe JG, Green MW. Quantitative exfoliative cytology of normal buccal mucosa: Effect of smoking. J Oral Pathol Med 1990;19:53-5.

11. Sugerman PB, Savage NW. Exfoliative cytology in clinical oral pathology. Aust Dent J 1996;41:71-4.

12. Ten Cate AR, editor. Oral histology: Development, structure and 
function. $5^{\text {th }}$ ed: United States: Mosby; 1998.

13. Pereira BR, Tanaka OM, Lima AA, Guariza-Filho O, Maruo H, Camargo ES. Metal and ceramic bracket effects on human buccal mucosa epithelial cells. Angle Orthod 2009;79:373-9.

14. Ramaesh T, Mendis BR, Ratnatunga N, Thattil RO. Cytomorphometric analysis of squames obtained from normal oral mucosa and lesions of oral leukoplakia and squamous cell carcinoma. J Oral Pathol Med 1998;27:83-6.

15. Shabana AH, el-Labban NG, Lee KW, Kramer IR. Morphometric analysis of suprabasal cells in oral white lesions. J Clin Pathol 1989;42:264-70.

16. Bernstein ML, Miller RL. Oral exfoliative cytology. J Am Dent Assoc 1978;96:625-9.

17. Hafez HS, Selim EM, Kamel Eid FH, Tawfik WA, Al-Ashkar EA, Mostafa YA. Cytotoxicity, genotoxicity, and metal release in patients with fixed orthodontic appliances: A longitudinal in-vivo study. Am J Orthod Dentofacial Orthop 2011;140:298-308.

18. Natarajan M, Padmanabhan S, Chitharanjan A, Narasimhan M.
Evaluation of the genotoxic effects of fixed appliances on oral mucosal cells and the relationship to nickel and chromium concentrations: An in-vivo study. Am J Orthod Dentofacial Orthop 2011;140:383-8.

19. Faccioni F, Franceschetti $\mathrm{P}$, Cerpelloni M, Fracasso ME. In vivo study on metal release from fixed orthodontic appliances and DNA damage in oral mucosa cells. Am J Orthod Dentofacial Orthop 2003;124:687-93.

20. Fernandez-Minano E, Ortiz C, Vicente A, Calvo JL, Ortiz AJ. Metallic ion content and damage to the DNA in oral mucosa cells of children with fixed orthodontic appliances. Biometals 2011;24:935-41.

21. Barrett RD, Bishara SE, Quinn JK. Biodegradation of orthodontic appliances. Part I. Biodegradation of nickel and chromium in vitro. Am J Orthod Dentofacial Orthop 1993;103:8-14.

How to cite this article: Sampaio Mei RM, Soares de Lima AA, Filho JB, Tanaka OM, Filho OG, Camargo ES. A cytological analysis of the oral mucosa adjacent to orthodontic devices. Eur J Gen Dent 2013;2:119-23.

Source of Support: Nil, Conflict of Interest: None declared.

\section{Author Help: Online submission of the manuscripts}

Articles can be submitted online from http://www.journalonweb.com. For online submission, the articles should be prepared in two files (first page file and article file). Images should be submitted separately.

1) First Page File:

Prepare the title page, covering letter, acknowledgement etc. using a word processor program. All information related to your identity should be included here. Use text/rtt/doc/pdf files. Do not zip the files.

2) Article File:

The main text of the article, beginning with the Abstract to References (including tables) should be in this file. Do not include any information (such as acknowledgement, your names in page headers etc.) in this file. Use text/rtt/doc/pdf files. Do not zip the files. Limit the file size to $1 \mathrm{MB}$. Do not incorporate images in the file. If file size is large, graphs can be submitted separately as images, without their being incorporated in the article file. This will reduce the size of the file.

3) Images:

Submit good quality color images. Each image should be less than $4096 \mathrm{~kb}(4 \mathrm{MB})$ in size. The size of the image can be reduced by decreasing the actual height and width of the images (keep up to about 6 inches and up to about $1800 \times 1200$ pixels). JPEG is the most suitable file format. The image quality should be good enough to judge the scientific value of the image. For the purpose of printing, always retain a good quality, high resolution image. This high resolution image should be sent to the editorial office at the time of sending a revised article.

4) Legends:

Legends for the figures/images should be included at the end of the article file. 